\title{
Management of Antiviral Resistance in Chronic Hepatitis B
}

\author{
Young-Suk Lim \\ Department of Gastroenterology, Liver Center, Asan Medical Center, University of Ulsan College of Medicine, Seoul, Korea
}

The primary goal of therapy for chronic hepatitis $B(\mathrm{CHB})$ is to prevent liver disease progression. Hepatitis B surface antigen (HBsAg) seroclearance or seroconversion is regarded as an optimal endpoint to discontinue treatment. However, HBsAg seroclearance occurs very rarely with nucleos(t)ide analog (NUC) treatment, and long-term, almost indefinite, NUC treatment is required for the majority of patients. In patients with drug-resistant hepatitis B virus (HBV), a combination of tenofovir disoproxil fumarate (TDF) and entecavir (ETV), which is currently regarded as the strongest combination therapy against HBV, would be potentially safe to prevent the emergence of additional HBV resistance mutations. However, long-term tolerance data are lacking, and cost may be an issue for combination therapies. Several recent, well-designed, randomized controlled trials have shown that TDF monotherapy provides similar antiviral efficacy compared with the combination of TDF and ETV. Furthermore, no additional HBV resistance mutations emerged during TDF monotherapy for up to 96 weeks. Considering a comparable antiviral efficacy, extremely low risk of TDF-resistance, lower cost, and better safety potential, TDF monotherapy would be a reasonable choice for the treatment of drug-resistant patients with $\mathrm{CHB}$.

(Gut Liver 2017;11:189-195)

Key Words: Adefovir; Entecavir; Lamivudine; Monotherapy; Tenofovir

\section{INTRODUCTION}

High serum hepatitis B virus (HBV) DNA levels are an independent risk factor for disease progression to cirrhosis and hepatocellular carcinoma (HCC) in patients with chronic hepatitis $\mathrm{B}(\mathrm{CHB}) .{ }^{1,2}$ By contrast, reducing HBV DNA concentrations to very low or undetectable levels through long-term nucleos(t)ide analogue (NUC) therapy is associated with reduced risk of mor- tality and/or HCC. . $^{3-11}$

Over the past two decades, treatment of CHB has greatly improved with the availability of NUCs, including lamivudine (LAM), adefovir (ADV), entecavir (ETV), telbivudine, and tenofovir, which target particular sites of viral polymerases. ${ }^{12-14}$ Particularly, with the availability of potent NUCs, such as tenofovir disoproxil fumarate (TDF) and ETV, suppression of serum HBV DNA to levels undetectable by polymerase chain reaction assays is achievable in most NUC treatment-naïve patients in the absence of drug-resistant HBV mutants (Fig. 1). ${ }^{15,16}$ However, many patients worldwide have developed drug-resistance from the widespread use of less potent NUCs, such as LAM or ADV, which have a low genetic barrier to resistance. Patients with persistent drug-resistant HBV viremia are more likely to suffer hepatitis flares, disease progression, and to die than those without drug-resistant HBV.,

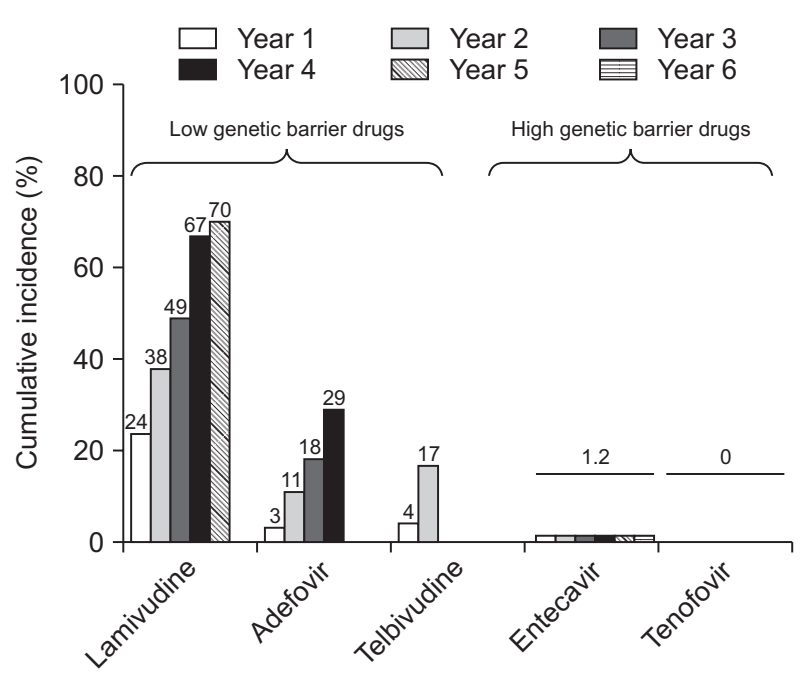

Fig. 1. Cumulative incidence of hepatitis $B$ virus resistance in pivotal trials. Adapted from EASL clinical practice guidelines. J Hepatol 2012;57:167-185. ${ }^{24}$

\footnotetext{
Correspondence to: Young-Suk Lim

Department of Gastroenterology, Asan Medical Center, University of Ulsan College of Medicine, 88 Olympic-ro 43-gil, Songpa-gu, Seoul 05505, Korea

Tel: +82-2-3010-5933, Fax: +82-2-485-5782, E-mail: limys@amc.seoul.kr

Received on November 2, 2015. Accepted on January 17, 2016. Published online February 13, 2017

pISSN 1976-2283 eISSN 2005-1212 https://doi.org/10.5009/gnl15562

(a) This is an Open Access article distributed under the terms of the Creative Commons Attribution Non-Commercial License (http://creativecommons.org/licenses/by-nc/4.0) which permits unrestricted non-commercial use, distribution, and reproduction in any medium, provided the original work is properly cited.
} 


\section{MECHANISM OF ANTIVIRAL DRUG RESISTANCE}

Nucleoside- and nucleotide-analogues selectively target HBV DNA polymerase, resulting in premature chain termination of viral replication. Drug-resistant strains of HBV have signature mutations in the reverse transcriptase domains of the viral polymerase gene (Table 1). Resistance mutations alter the interaction between HBV polymerase and drug, which interfere the inhibitory effect of drug on viral polymerase. After emergence of primary resistance mutations, compensatory mutations that restore replication capacity may arise (Fig. 2), as well as secondary resistance mutations that increase drug resistance when they accumulate on the same viral genome.

Once antiviral-resistant HBV mutants have been selected, they are persistently retained in the virus population even if treatment is stopped, and exerts cross-resistance to the next sequential monotherapy (Fig. 2)..$^{14,17,18}$ For example, ADV-resistant mutations emerge more frequently during $\mathrm{ADV}$ monotherapy in LAM-resistant than in treatment-naïve patients. ${ }^{19-21}$ The rate of ETV resistance increases up to 51\% after 5 years of ETV treatment in patients with LAM-resistant HBV, which is in striking contrast to a $1.2 \%$ resistance rate in NUC-naïve patients. ${ }^{22,23}$ Thus, combination therapy with a nucleoside analogue (LAM, telbivudine, or ETV) and a nucleotide analogue (ADV or TDF) has generally been recommended for the treatment of patients harboring drug-resistant HBV. ${ }^{14,24-26}$ However, several recent studies including ours have suggested that TDF monotherapy is efficacious in patients with LAM-resistant, ETV-resistant, or ADV-resistant $\mathrm{HBV}^{27-32}$

\section{MANAGEMENT OF RESISTANCE TO LAMIVUDINE}

For LAM-resistant patients, a combination of ADV and LAM showed no greater antiviral efficacy than ADV monotherapy. ${ }^{33}$

Table 1. Summary of In Vitro Cross-Resistance for Hepatitis B Virus Variants

\begin{tabular}{|c|c|c|c|c|}
\hline HBV variant & Lamivudine & Entecavir & Adefovir & Tenofovir \\
\hline Wild-type & $\mathrm{S}$ & $\mathrm{S}$ & $\mathrm{S}$ & $\mathrm{S}$ \\
\hline M204V/I & $\mathrm{R}$ & I & I & $\mathrm{S}$ \\
\hline L180M+M204V & $\mathrm{R}$ & I & $\mathrm{I}$ & $\mathrm{S}$ \\
\hline $\mathrm{A} 181 \mathrm{~T} / \mathrm{V}$ & $\mathrm{R}$ & $\mathrm{S}$ & $\mathrm{R}$ & $\mathrm{S}$ \\
\hline $\mathrm{N} 236 \mathrm{~T}$ & $\mathrm{~S}$ & $\mathrm{~S}$ & $\mathrm{R}$ & I \\
\hline $\mathrm{A} 181 \mathrm{~T} / \mathrm{V}+\mathrm{N} 236 \mathrm{~T}$ & $\mathrm{R}$ & $\mathrm{S}$ & $\mathrm{R}$ & I \\
\hline $\mathrm{L} 180 \mathrm{M}+\mathrm{M} 204 \mathrm{~V} / \mathrm{I} \pm \mathrm{T} 184$ & $\mathrm{R}$ & $\mathrm{R}$ & $\mathrm{S}$ & $\mathrm{S}$ \\
\hline $\mathrm{L} 180 \mathrm{M}+\mathrm{M} 204 \mathrm{~V} / \mathrm{I}_{ \pm} \mathrm{S} 202$ & $\mathrm{R}$ & $\mathrm{R}$ & $\mathrm{S}$ & $\mathrm{S}$ \\
\hline $\mathrm{L} 180 \mathrm{M}+\mathrm{M} 204 \mathrm{~V} / \mathrm{I}_{ \pm} \mathrm{I} 169 \mathrm{~T} \pm \mathrm{M} 250$ & $\mathrm{R}$ & $\mathrm{R}$ & $\mathrm{S}$ & $\mathrm{S}$ \\
\hline
\end{tabular}

HBV, hepatitis B virus; S, sensitive; I, intermediate/reduced susceptibility; R, resistant.

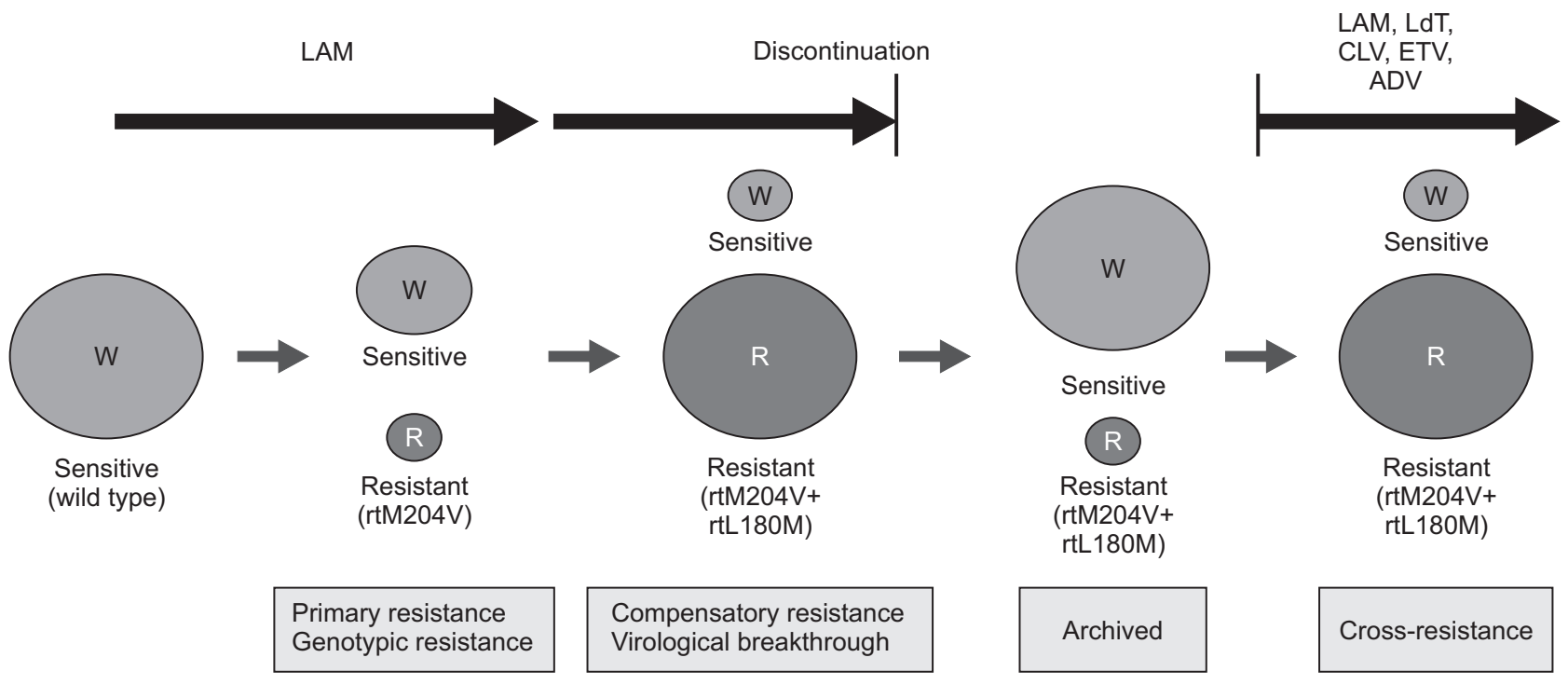

Fig. 2. Evolution of drug-resistant hepatitis B virus. Adapted from Bartholomeusz A, et al. Semin Liver Dis 2006;26:162-170. ${ }^{64}$; Fournier C, et al. Clin Liver Dis 2007;11:869-892..$^{65}$

LAM, lamivudine; LdT, telbivudine; CLV, clevudine; ETV, entecavir; ADV, adefovir dipivoxil; W, wild type HBV strain; R, resistant HBV strain. 
Nonetheless, ADV and LAM combination therapy had been recommended for these patients to prevent additional emergence of ADV-resistant HBV mutants. ${ }^{14,20,24,25,34-36}$

However, the situation is clearly different if TDF, that has about 30 times higher anti-HBV potency than ADV, is used instead of ADV. Treatment responses to TDF and LAM combination therapy would likely be mediated by TDF alone, since LAM may have no or minimal antiviral efficacy in the presence of LAM-resistant HBV mutants. With this combination, continued LAM treatment would likely only help prevent the development of TDF-resistance mutations, rather than increasing antiviral potency. Therefore, if there is minimal risk of TDF-resistance, ${ }^{16,37}$ the addition of LAM to TDF would theoretically provide little benefit. The hypothesis was actually proven by a recent randomized double-blind controlled trial. ${ }^{29}$ The study showed that TDF monotherapy was highly efficacious in patients with LAM-resistant HBV, which was comparable to the combination of TDF and emtricitabine, without emergence of additional resistance mutations to TDF throughout 96 weeks of treatment (Fig. 3). ${ }^{29,37}$ Entricitabine is an unapproved nucleoside analogue which has very similar anti-HBV potency and barrier to resistance development as LAM. Thus, the study results indicate that adding LAM to TDF would not provide additional antiviral benefit, and that TDF monotherapy is safe and efficacious to patients with LAM-resistant HBV.

\section{MANAGEMENT OF RESISTANCE TO LAM AND ETV}

In patients with pre-existing LAM-resistance, the rate of ETV resistance increases up to $51 \%$ after 5 years of ETV treatment, which is in striking contrast to a $1.2 \%$ resistance rate in NUC-

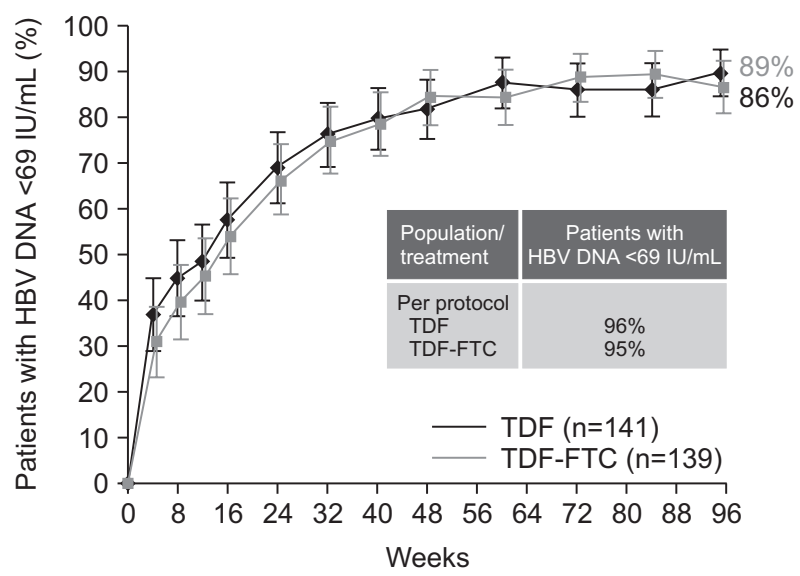

Fig. 3. Virologic response (hepatitis $B$ virus $[\mathrm{HBV}] \mathrm{DNA}<60 \mathrm{IU} / \mathrm{mL}$ ) by tenofovir disoproxil fumarate (TDF) monotherapy versus TDF and emtricitabine combination therapy in lamivudine-resistant patients with chronic hepatitis B in a randomized double-blind controlled trial. Intention-to-treat population shown. Adapted from Fung S, et al. Gastroenterology 2014;146:980-988.e1, with permission from Elsevier. $^{29}$

FTC, emtricitabine. naïve patients. ${ }^{22,23}$ In addition, ETV monotherapy was suboptimal in suppressing HBV replication in patients with LAMresistant $\mathrm{HBV}$, with an unacceptably low virologic response rate $(22 \%)$ seen at 12 months. ${ }^{38,39}$ This difference is because the ETV resistance barrier is lowered by the initial selection of the LAM-resistant HBV mutation, rtM204V/I. ${ }^{40}$ In vitro studies have shown that susceptibility to ETV is decreases by 10 - to 250fold when one of the ETV resistance-associated substitutions at rtT184, rtS202, or rtM250 is present in combination with rtM204V/I, and by >500-fold when two or more of these mutations are present. ${ }^{22,40}$

In vitro studies suggest that ETV-resistant HBV mutants are susceptible to TDF. ${ }^{17,41}$ These in vitro studies showed that HBV strains harboring the ETV resistance-associated substitutions, rtM204V/I, rtT184, rtS202, and/or rtM250, exhibit no crossresistance to tenofovir. ${ }^{17,41}$ Several case reports and retrospective cohort studies also showed the clinical efficacy of TDF in ETVresistant or ETV-refractory patients. ${ }^{42-44}$

In our recent multicenter randomized trial, patients who had HBV with ETV resistance-associated mutations and serum HBV DNA concentrations $>60 \mathrm{IU} / \mathrm{mL}$ were randomized to receive TDF (300 mg/day) monotherapy ( $\mathrm{n}=45)$ or TDF and ETV ( $1 \mathrm{mg} /$ day) combination therapy $(n=45)$. At week 48 , the proportion of patients with HBV DNA < $15 \mathrm{IU} / \mathrm{mL}$, the primary efficacy endpoint, was not significantly different between the TDF and TDF+ETV groups $(71 \%$ vs $73 \%, p=0.81)$. The proportion of patients who achieved HBV DNA levels $<60 \mathrm{IU} / \mathrm{mL}$ at week 48 was $82 \%$ and $89 \%$ for the TDF and TDF+ETV groups, respectively $(p=0.55)$ (Fig. 4). The mean change in HBV DNA levels from baseline was not significantly different between groups $\left(-3.65 \log _{10} \mathrm{IU} /\right.$ $\mathrm{mL}$ vs $\left.-3.77 \log _{10} \mathrm{IU} / \mathrm{mL}, \mathrm{p}=0.69\right)$. Virologic breakthrough occurred in one patient on TDF, which was attributed to poor drug

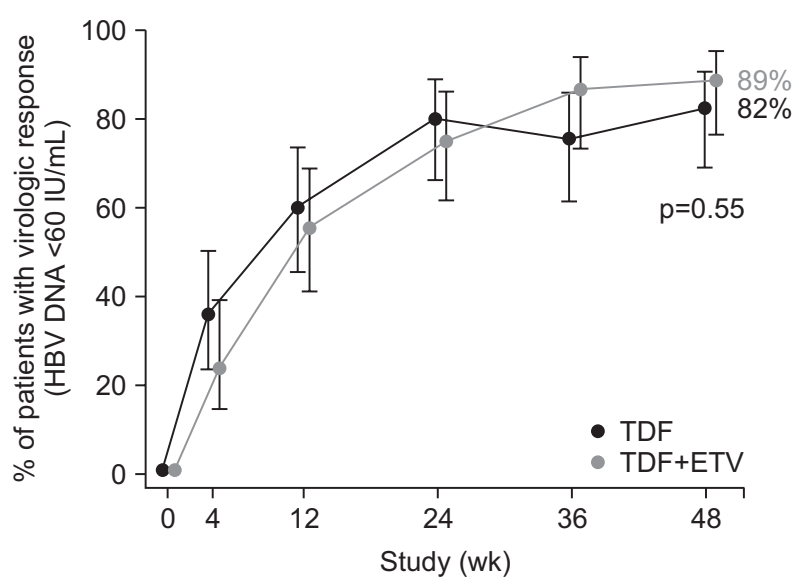

Fig. 4. Virologic response (hepatitis B virus [HBV] DNA $<60 \mathrm{IU} / \mathrm{mL}$ ) by tenofovir disoproxil fumarate (TDF) monotherapy versus TDF and entecavir (ETV) combination therapy in ETV-resistant patients with chronic hepatitis B in a randomized controlled trial. Intention-to-treat population shown. Adapted from Lim YS, et al. Gut 2016;65:852$860 .^{31}$ 
adherence. At week 48, six and three patients in the TDF and TDF+ETV groups, respectively, retained their baseline resistance mutations ( $p>0.99$ ). None developed additional resistance mutations. Safety profiles were comparable in the two groups. The rate of virologic response by TDF monotherapy in our study was similar with that of a recent single arm trial with TDF+ETV in CHB patients with previous NUC treatment failure (85\% had HBV DNA $<50 \mathrm{IU} / \mathrm{mL}$ at week 96$).{ }^{45}$ These results support the view that TDF monotherapy may be a treatment option for patients with ETV-resistant HBV.

\section{MANAGEMENT OF RESISTANCE TO LAM AND ADV}

In vitro clonal analyses showed that multidrug-resistance mutations usually reside in the same viral genome, ${ }^{18,46}$ and antiviral sensitivities revealed that replicating clones with LAMand ADV-associated mutations had $>50$-fold reduced susceptibility to combination of LAM and $\mathrm{ADV}^{47,48}$ In fact, our previous cohort study demonstrated that, in patients with HBV resistant to LAM and ADV, combination therapy with these two drugs was not effective and was even inferior to ETV monotherapy in suppressing HBV DNA. ${ }^{49}$ However, the response to ETV monotherapy was not optimal. We demonstrated that ETV was far less effective in patients refractory to both LAM and ADV than in those with LAM mono-resistance. ${ }^{50}$

In vitro studies have shown that HBV strains expressing the ADV resistance-associated substitutions, rtA181T/V and/or rtN236T, demonstrate reduced susceptibility to tenofovir, ranging from 2.9- to 10-fold of that of the wild-type virus. ${ }^{46,51-53}$ Several cohort studies also showed reduced TDF efficacy in patients with ADV-resistant HBV. ${ }^{30,54}$ An European cohort study showed that, the probability of achieving HBV DNA levels below 400 copies/mL was significantly lower with TDF monotherapy in patients with $\mathrm{ADV}$-resistant $\mathrm{HBV}$ and high viral load ( $>10^{7}$ copies $/ \mathrm{mL}$ ) at baseline compared with those without ADV-resistant HBV. ${ }^{54}$ Another cohort study also showed that the efficacy of TDF was lower in patients with ADV-resistant HBV than in treatment-naïve patients, especially when they had previously failed to respond to both $\mathrm{LAM}$ and $\mathrm{ADV} .{ }^{30}$ On the other hand, a combination of TDF and ETV, which is currently regarded as the strongest combination therapy against HBV, induced a virologic response in up to $90 \%$ of patients after a median 6 months of treatment regardless of preexisting ADVor ETV-resistance. ${ }^{55}$ However, whether a combination of TDF and ETV exerts better antiviral efficacy than TDF monotherapy in patients with multidrug-resistant HBV could not be identified by these single arm studies.

We recently performed a multicenter trial, in which, patients who had ADV-resistant HBV with serum HBV DNA levels >60 $\mathrm{IU} / \mathrm{mL}$ were randomized to receive TDF (300 mg/day) monotherapy $(\mathrm{n}=50)$ or TDF and ETV (1 mg/day) combination therapy (TDF/ETV, $n=52$ ) for 48 weeks. All patients had ADV-resistant

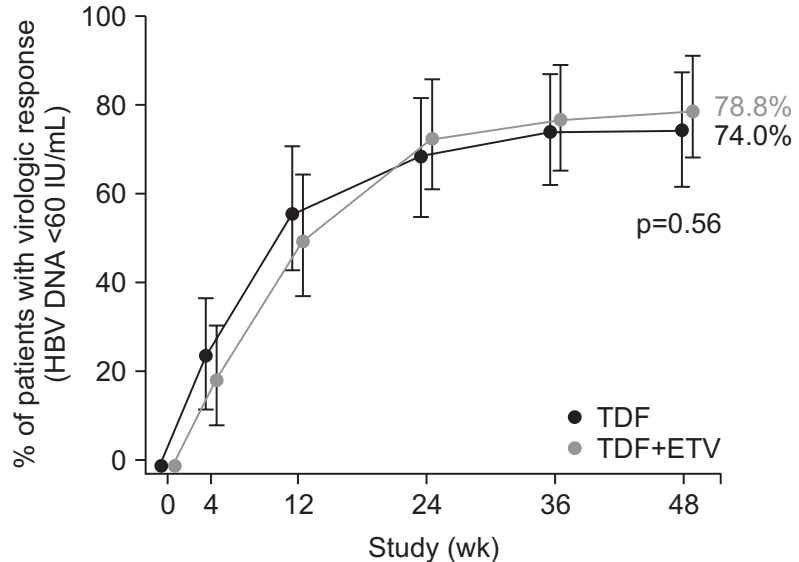

Fig. 5. Virologic response (hepatitis B virus [HBV] DNA $<60 \mathrm{IU} /$ $\mathrm{mL}$ ) by tenofovir disoproxil fumarate (TDF) monotherapy versus TDF and entecavir (ETV) combination therapy in adefovir-resistant patients with chronic hepatitis B in a randomized controlled trial. Intention-to-treat population shown. Adapted from Lim YS, et al. Gut 2016;65:1042-1051.32

HBV mutations; rtA181V/T and/or rtN236T. The proportion of patients with $\mathrm{HBV}$ DNA $<15 \mathrm{IU} / \mathrm{mL}$ was not significantly different between the TDF-TDF and TDF/ETV-TDF groups at week 48 (62\% vs 63.5\%, $\mathrm{p}=0.88$ ) and at week 96 (64\% vs 63.5\%, $\mathrm{p}=0.96$ ). The proportion of patients who achieved HBV DNA levels $<60$ $\mathrm{IU} / \mathrm{mL}$ at week 48 was $74 \%$ and $78.8 \%$ for the TDF-TDF and TDF/ETV-TDF groups, respectively $(\mathrm{p}=0.56)$ (Fig. 5). Virologic breakthrough occurred in one patient on TDF-TDF and two patients on TDF/ETV-TDF over 96 weeks; all were attributed to poor drug adherence. At week 96, five and two patients in the TDF-TDF and TDF/ETV-TDF groups, respectively, retained some of their baseline resistance mutations $(\mathrm{p}=0.44)$. None developed additional resistance mutations. Safety profiles were comparable in the two groups. The results suggest that TDF monotherapy may be a treatment option for patients with ADV-resistant HBV. However, in a subgroup of patients who had double ADV-resistance mutations, i.e., both rtA181T/V and rtN236T, the decrease in serum HBV DNA levels tended to be less in the TDF group than in the TDF/ETV-TDF group. Thus, TDF plus ETV combination therapy might be more beneficial than TDF monotherapy in patients who had double ADV-resistance mutations (both rtA181T/V and rtN236T).

\section{CONCLUSIONS}

The primary goal of therapy for CHB is to prevent liver disease progression, and seroclearance or seroconversion of hepatitis B surface antigen ( $\mathrm{HBsAg}$ ) is regarded as an optimal endpoint of treatment. ${ }^{56}$ However, HBsAg seroclearance occurs very rarely with NUC treatment. ${ }^{56}$ Long-term HBV DNA and HBsAg level kinetics in patients with CHB treated with potent NUCs showed that HBsAg clearance is unlikely to occur during the 
patient's lifetime, even if HBV replication is well controlled. ${ }^{57}$ Thus, long-term, almost indefinite, NUC treatment is required for the majority of patients.

In patients with drug-resistant HBV, a combination of TDF and ETV would be potentially safer to prevent the emergence of resistance to TDF..$^{58}$ However, long-term tolerance data are lacking and cost may be an issue for this combination. Considering a comparable antiviral efficacy, extremely low risk of TDFresistance, lower cost, and potentially better safety profile, TDF monotherapy would be a reasonable option for the treatment of ETV-resistant patients. In fact, TDF monotherapy is now being incorporated as a primary recommendation for the treatment of patients with drug-resistant HBV in many recent practice guidelines (Table 2). ${ }^{24,59-62}$ However, the rates of virologic response in multidrug-resistant patients seem to be lower compared to those reported in previous clinical trials of TDF in treatment-naïve, LAM-resistant, or ADV-refractory patients. ${ }^{27,29,63}$ Because the combination of TDF and ETV does not seem to further increase the rate of virologic response, a more potent antiviral agent may be required for patients with $\mathrm{HBV}$ mutants resistant to multiple drugs including $\mathrm{ADV}$.

\section{CONFLICTS OF INTEREST}

Y.S.L. is an advisory board member of Bayer Healthcare, Bristol-Myers Squibb, and Gilead Sciences, and receives research funding from Bayer Healthcare, Bristol-Myers Squibb, Gilead Sciences, and Novartis.

\section{ACKNOWLEDGEMENTS}

This study was supported by grants from the Korean National Health Clinical Research (NHCR) project, Ministry of Health \& Welfare, Republic of Korea (HC15C3380); the Korean Health Technology R\&D Project, Ministry of Health \& Welfare, Republic of Korea (HI14C1061); and the Proteogenomic Research Program through the National Research Foundation (NRF2015M3C9A1044530) of Korea funded by the Korea government.

\section{REFERENCES}

1. Chen CJ, Yang HI, Su J, et al. Risk of hepatocellular carcinoma across a biological gradient of serum hepatitis B virus DNA level. JAMA 2006;295:65-73.

2. Iloeje UH, Yang HI, Su J, et al. Predicting cirrhosis risk based on the level of circulating hepatitis B viral load. Gastroenterology 2006;130:678-686.

3. Liaw YF, Sung JJ, Chow WC, et al. Lamivudine for patients with chronic hepatitis B and advanced liver disease. N Engl J Med 2004;351:1521-1531.

4. Gordon SC, Lamerato LE, Rupp LB, et al. Antiviral therapy for 
chronic hepatitis B virus infection and development of hepatocellular carcinoma in a US population. Clin Gastroenterol Hepatol 2014;12:885-893.

5. Eun JR, Lee HJ, Kim TN, Lee KS. Risk assessment for the development of hepatocellular carcinoma: according to on-treatment viral response during long-term lamivudine therapy in hepatitis B virus-related liver disease. J Hepatol 2010;53:118-125.

6. Papatheodoridis GV, Dimou E, Dimakopoulos K, et al. Outcome of hepatitis B e antigen-negative chronic hepatitis B on long-term nucleos(t)ide analog therapy starting with lamivudine. Hepatology 2005;42:121-129.

7. Yuen MF, Seto WK, Chow DH, et al. Long-term lamivudine therapy reduces the risk of long-term complications of chronic hepatitis B infection even in patients without advanced disease. Antivir Ther 2007;12:1295-1303.

8. Hosaka T, Suzuki F, Kobayashi M, et al. Long-term entecavir treatment reduces hepatocellular carcinoma incidence in patients with hepatitis B virus infection. Hepatology 2013;58:98-107.

9. Wong GL, Chan HL, Mak CW, et al. Entecavir treatment reduces hepatic events and deaths in chronic hepatitis B patients with liver cirrhosis. Hepatology 2013;58:1537-1547.

10. Lim YS, Han S, Heo NY, Shim JH, Lee HC, Suh DJ. Mortality, liver transplantation, and hepatocellular carcinoma among patients with chronic hepatitis B treated with entecavir vs lamivudine. Gastroenterology 2014;147:152-161.

11. Wu CY, Lin JT, Ho HJ, et al. Association of nucleos(t)ide analogue therapy with reduced risk of hepatocellular carcinoma in patients with chronic hepatitis B: a nationwide cohort study. Gastroenterology 2014;147:143-151.e5.

12. European Association for the Study of the Liver. EASL clinical practice guidelines: management of chronic hepatitis B. J Hepatol 2009;50:227-242.

13. Keeffe EB, Dieterich DT, Han SH, et al. A treatment algorithm for the management of chronic hepatitis B virus infection in the United States: 2008 update. Clin Gastroenterol Hepatol 2008;6:13151341.

14. Lok AS, McMahon BJ. Chronic hepatitis B: update 2009. Hepatology 2009;50:661-662.

15. Chang TT, Lai CL, Kew Yoon S, et al. Entecavir treatment for up to 5 years in patients with hepatitis B e antigen-positive chronic hepatitis B. Hepatology 2010;51:422-430.

16. Kitrinos KM, Corsa A, Liu Y, et al. No detectable resistance to tenofovir disoproxil fumarate after 6 years of therapy in patients with chronic hepatitis B. Hepatology 2014;59:434-442.

17. Zoulim F, Locarnini S. Management of treatment failure in chronic hepatitis B. J Hepatol 2012;56 Suppl 1:S112-S122.

18. Yim HJ, Hussain M, Liu Y, Wong SN, Fung SK, Lok AS. Evolution of multi-drug resistant hepatitis B virus during sequential therapy. Hepatology 2006;44:703-712.

19. Fung SK, Chae HB, Fontana RJ, et al. Virologic response and resistance to adefovir in patients with chronic hepatitis B. J Hepatol 2006;44:283-290.
20. Lee YS, Suh DJ, Lim YS, et al. Increased risk of adefovir resistance in patients with lamivudine-resistant chronic hepatitis B after 48 weeks of adefovir dipivoxil monotherapy. Hepatology 2006;43:1385-1391.

21. Yeon JE, Yoo W, Hong SP, et al. Resistance to adefovir dipivoxil in lamivudine resistant chronic hepatitis B patients treated with adefovir dipivoxil. Gut 2006;55:1488-1495.

22. Tenney DJ, Rose RE, Baldick CJ, et al. Two-year assessment of entecavir resistance in Lamivudine-refractory hepatitis B virus patients reveals different clinical outcomes depending on the resistance substitutions present. Antimicrob Agents Chemother 2007;51:902-911.

23. Tenney DJ, Rose RE, Baldick CJ, et al. Long-term monitoring shows hepatitis B virus resistance to entecavir in nucleosidenaïve patients is rare through 5 years of therapy. Hepatology 2009;49:1503-1514.

24. European Association for the Study of the Liver. EASL clinical practice guidelines: management of chronic hepatitis B virus infection. J Hepatol 2012;57:167-185.

25. Korean Association for the Study of the Liver. KASL clinical practice guidelines: management of chronic hepatitis B. Clin Mol Hepatol 2012;18:109-162.

26. Liaw YF, Kao JH, Piratvisuth T, et al. Asian-Pacific consensus statement on the management of chronic hepatitis B: a 2012 update. Hepatol Int 2012;6:531-561.

27. Berg T, Marcellin P, Zoulim F, et al. Tenofovir is effective alone or with emtricitabine in adefovir-treated patients with chronichepatitis B virus infection. Gastroenterology 2010;139:1207-1217.

28. Berg T, Zoulim F, Moeller B, et al. Long-term efficacy and safety of emtricitabine plus tenofovir DF vs. tenofovir DF monotherapy in adefovir-experienced chronic hepatitis B patients. J Hepatol 2014;60:715-722.

29. Fung S, Kwan P, Fabri M, et al. Randomized comparison of tenofovir disoproxil fumarate vs emtricitabine and tenofovir disoproxil fumarate in patients with lamivudine-resistant chronic hepatitis B. Gastroenterology 2014;146:980-988.e1.

30. Patterson SJ, George J, Strasser SI, et al. Tenofovir disoproxil fumarate rescue therapy following failure of both lamivudine and adefovir dipivoxil in chronic hepatitis B. Gut 2011;60:247-254.

31. Lim YS, Byun KS, Yoo BC, et al. Tenofovir monotherapy versus tenofovir and entecavir combination therapy in patients with entecavir-resistant chronic hepatitis B with multiple drug failure: results of a randomised trial. Gut 2016;65:852-860.

32. Lim YS, Yoo BC, Byun KS, et al. Tenofovir monotherapy versus tenofovir and entecavir combination therapy in adefovir-resistant chronic hepatitis B patients with multiple drug failure: results of a randomised trial. Gut 2016;65:1042-1051.

33. Peters MG, Hann HW, Martin P, et al. Adefovir dipivoxil alone or in combination with lamivudine in patients with lamivudineresistant chronic hepatitis B. Gastroenterology 2004;126:91-101.

34. Liaw YF, Leung N, Kao JH, et al. Asian-Pacific consensus statement on the management of chronic hepatitis B: a 2008 update. 
Hepatol Int 2008;2:263-283.

35. Rapti I, Dimou E, Mitsoula P, Hadziyannis SJ. Adding-on versus switching-to adefovir therapy in lamivudine-resistant HBeAgnegative chronic hepatitis B. Hepatology 2007;45:307-313.

36. Lampertico P, Viganò M, Manenti E, Iavarone M, Sablon E, Colombo M. Low resistance to adefovir combined with lamivudine: a 3-year study of 145 lamivudine-resistant hepatitis B patients. Gastroenterology 2007;133:1445-1451.

37. Corsa AC, Liu Y, Flaherty JF, et al. No resistance to tenofovir disoproxil fumarate through 96 weeks of treatment in patients with lamivudine-resistant chronic hepatitis B. Clin Gastroenterol Hepatol 2014;12:2106-2112.e1.

38. Chang TT, Gish RG, Hadziyannis SJ, et al. A dose-ranging study of the efficacy and tolerability of entecavir in Lamivudine-refractory chronic hepatitis B patients. Gastroenterology 2005;129:11981209.

39. Sherman M, Yurdaydin C, Sollano J, et al. Entecavir for treatment of lamivudine-refractory, HBeAg-positive chronic hepatitis B. Gastroenterology 2006;130:2039-2049.

40. Tenney DJ, Levine SM, Rose RE, et al. Clinical emergence of entecavir-resistant hepatitis B virus requires additional substitutions in virus already resistant to Lamivudine. Antimicrob Agents Chemother 2004;48:3498-3507.

41. Villet S, Ollivet A, Pichoud C, et al. Stepwise process for the development of entecavir resistance in a chronic hepatitis B virus infected patient. J Hepatol 2007;46:531-538.

42. Pan CQ, Hu KQ, Yu AS, Chen W, Bunchorntavakul C, Reddy KR. Response to tenofovir monotherapy in chronic hepatitis B patients with prior suboptimal response to entecavir. J Viral Hepat 2012;19:213-219.

43. Yip B, Chaung K, Wong CR, et al. Tenofovir monotherapy and tenofovir plus entecavir combination as rescue therapy for entecavir partial responders. Dig Dis Sci 2012;57:3011-3016.

44. Leemans WF, Niesters HG, van der Eijk AA, Janssen HL, Schalm SW, de Man RA. Selection of an entecavir-resistant mutant despite prolonged hepatitis B virus DNA suppression, in a chronic hepatitis B patient with preexistent lamivudine resistance: successful rescue therapy with tenofovir. Eur J Gastroenterol Hepatol 2008;20:773-777.

45. Zoulim F, Jablkowski MS, Diculescu M, et al. The safety and efficacy of entecavir and tenofovir combination therapy for chronic hepatitis B in patients with previous nucleos(t)ide treatment failure: week 96 results of the ENTEBE study. Hepatology 2014;60(Suppl 4):314A-315A.

46. Villet S, Pichoud C, Villeneuve JP, Trépo C, Zoulim F. Selection of a multiple drug-resistant hepatitis B virus strain in a livertransplanted patient. Gastroenterology 2006;131:1253-1261.

47. Villeneuve JP, Durantel D, Durantel S, et al. Selection of a hepatitis B virus strain resistant to adefovir in a liver transplantation patient. J Hepatol 2003;39:1085-1089.

48. Angus P, Vaughan R, Xiong $S$, et al. Resistance to adefovir dipivoxil therapy associated with the selection of a novel mutation in the HBV polymerase. Gastroenterology 2003;125:292-297.

49. Heo NY, Lim YS, Lee HC, Chung YH, Lee YS, Suh DJ. Lamivudine plus adefovir or entecavir for patients with chronic hepatitis B resistant to lamivudine and adefovir. J Hepatol 2010;53:449-454.

50. Shim JH, Suh DJ, Kim KM, et al. Efficacy of entecavir in patients with chronic hepatitis B resistant to both lamivudine and adefovir or to lamivudine alone. Hepatology 2009;50:1064-1071.

51. Brunelle MN, Jacquard AC, Pichoud C, et al. Susceptibility to antivirals of a human HBV strain with mutations conferring resistance to both lamivudine and adefovir. Hepatology 2005;41:1391-1398.

52. Villet S, Pichoud C, Billioud G, et al. Impact of hepatitis B virus rtA181V/T mutants on hepatitis B treatment failure. J Hepatol 2008;48:747-755.

53. Qi X, Xiong S, Yang H, Miller M, Delaney WE 4th. In vitro susceptibility of adefovir-associated hepatitis B virus polymerase mutations to other antiviral agents. Antivir Ther 2007;12:355-362.

54. van Bömmel F, de Man RA, Wedemeyer H, et al. Long-term efficacy of tenofovir monotherapy for hepatitis B virus-monoinfected patients after failure of nucleoside/nucleotide analogues. Hepatology 2010;51:73-80.

55. Petersen J, Ratziu V, Buti M, et al. Entecavir plus tenofovir combination as rescue therapy in pre-treated chronic hepatitis B patients: an international multicenter cohort study. J Hepatol 2012;56:520-526.

56. Kim GA, Lim YS, An J, et al. HBsAg seroclearance after nucleoside analogue therapy in patients with chronic hepatitis B: clinical outcomes and durability. Gut 2014;63:1325-1332.

57. Chevaliez S, Hézode C, Bahrami S, Grare M, Pawlotsky JM. Long-term hepatitis B surface antigen (HBsAg) kinetics during nucleoside/nucleotide analogue therapy: finite treatment duration unlikely. J Hepatol 2013;58:676-683.

58. Pawlotsky JM. Is hepatitis virus resistance to antiviral drugs a threat? Gastroenterology 2012;142:1369-1372.

59. Terrault NA, Bzowej NH, Chang KM, et al. AASLD guidelines for treatment of chronic hepatitis B. Hepatology 2016;63:261-283.

60. World Health Organization. Guidelines for the prevention, care and treatment of persons with chronic hepatitis B infection. Geneva: World Health Organization; 2015.

61. Sarin SK, Kumar M, Lau GK, et al. Asian-Pacific clinical practice guidelines on the management of hepatitis B: a 2015 update. Hepatol Int 2016;10:1-98.

62. Korean Association for the Study of Liver. KASL clinical practice guidelines: management of chronic hepatitis B. Seoul: Korean Association for the Study of Liver, 2015.

63. Marcellin P, Heathcote EJ, Buti M, et al. Tenofovir disoproxil fumarate versus adefovir dipivoxil for chronic hepatitis B. N Engl J Med 2008;359:2442-2455.

64. Bartholomeusz A, Locarnini SA. Antiviral drug resistance: clinical consequences and molecular aspects. Semin Liver Dis 2006;26:162-170.

65. Fournier C, Zoulim F. Antiviral therapy of chronic hepatitis B: prevention of drug resistance. Clin Liver Dis 2007;11:869-892, ix. 